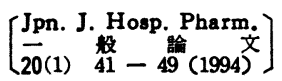

\title{
高龄者向け吸水膨潤型圧縮コーティング鎵の検討
}

\author{
伊東明彦*, 土橋結花, 小幡かおり, 杉原正泰 \\ 東京女子医科大学病院薬凧部
}

\section{Investigation of Compressed Coating Tablet Swelling with Water as a New Dosage Form for Elderly Patients}

\author{
AKIHIKo ITO*, YUKA DOBASHI, KAORI \\ ObATA, and MASAYASU SUgIHARA \\ Hospital Pharmacy, Tokyo Women's Medical College†
}

( $\left.\begin{array}{ll}\text { Received December } 16, & 1993 \\ \text { Accepted December } 22, & 1993\end{array}\right)$

The compressed coating tablet swelling with water was investigated for the purpose of development of a new dosage form for elderly patients. The dry gels of agar, gelatin, and Inaagar- $L^{\otimes}$ were reduced to powders and used as the coating material.

It was found that the surface of any tablet formed a state of jelly through the addition of water, thus masking the taste of the drug. All tablets satisfied the rules of the disintegration test outlined in JP XII. These tablets demonstrated high moisture absorption due to the stored condition. The water absorption pattern of the tablets varied with the kind of coating material used. The agar coating tablet absorbed water rapidly, with its coating layer then being disintegrated. The differences in water absorption and swelling behavior of these tablets were considered to be caused by the difference in the size of the gap between the gel particles of the coating layer and the swelling ability of the gel particles. The Inaagar-L coating tablet was deemed to be the most desirable one in the volunteer test. Therefore, it seems likely that the texture of the swelled coating layer is an important factor in facilitating swallowing.

Keywords-compressed coating tablet, swelling, dry gel powder, new dosage form, elderly, moisture absorption, agar, gelatin, Inaagar-L ${ }^{\circledR}$.

近年, わが国は急速に高龄化が進み21世紀には 4 人に 1 人が 65 歳以上の老人になる超高龄化社会 となることが予測されている．高龄者の有病率は 高く，ことに65歳以上になるとその数は急增して くる.ささら高龄者の疾患の特徵としては, 複数 の疾患を同時にもち，慢性の経過をたどる傾向に ある。

高龄化に伴い生理機能および身体機能が低下し

†東京都新宿区河田町8-1；8-1, Kawada-cho, Shinjuku-ku, Tokyo, 162 Japan
た高路者にとって長期間薬を服用することは困難 となっている，とくに，従来の剂形では服用でき ない高齢者に拈いても服用可能な剂形の開発が望 まれている，現在，内服用の固形製剂としては錠 剤, 散剤および顆粒剂などがあるが，シルバーサ イエンス研究における高齢者に対する調査 ${ }^{1)}$ では 散剤は口中での広がり, 喉への付着, 苦味などに よる残留感があげられ，顆粒剤は義歯の間に入り 込むなどの不快感があるなどの理由から錠剤を好 む傾向にあると報告されている．また苦味も服用 
乙難い原因であることから, 散剤, 顆粒剂に比べ味 も感じにくいと考えられる錠剤は高龄者にとって

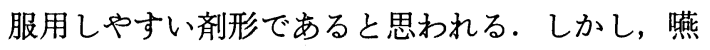
下機能が低下した高秢者にとって錠剤は嚥下し難 い場合もあり，服用し易いゼリ一状の剂形を希望 する報告1)もある. ゼリ一状の剂形は多量の水分 を含有するため微生物学的, 物理化学的安定性お よび味の点で問題が多い.

そこで高分子から調製したキセロゲルが水を吸 水し膨潤してヒドロゲルにもどることに着目し， キセロゲルでコーティング層を形成させた吸水膨 潤型圧縮コーティング錠の基礎的検討を行った. 本錠はコーティングするため味のマスキングも可 能と思われ, 保存中は固形であるが, 服用時, 水 を添加することによって錠剤表面がゼリ一状とな り服用し易くなると考えられる.

\section{実 験 の 部}

\section{1. 試料}

モデル薬物として漢方製剤エキス粒顆の呉荣鄚 湯（ツムラ）を用いた.コーティング用試料とし てはゼラチン (日局), 食品用ゼリーの素イナア ガーL（伊那食品工業）および伊那寒天 $\mathrm{T}-1$ （伊 那食品工業）を用いた. イナアガーLの組成 ${ }^{2)}$ Table 1 に示した.

Table 1. Composition of Inaagar-L ${ }^{\circledR}$

\begin{tabular}{lc} 
Carrageenan & 9.6 \\
Locust bean gum & 8.4 \\
Potassium chloride & 2.3 \\
Konobasic potassium phoshate & 2.3 \\
Calcium lactate & 0.6 \\
Trisodium citrate & 0.4 \\
Dibasic sodium phosphate & 0.2 \\
Food materials & 76.2 \\
\hline
\end{tabular}

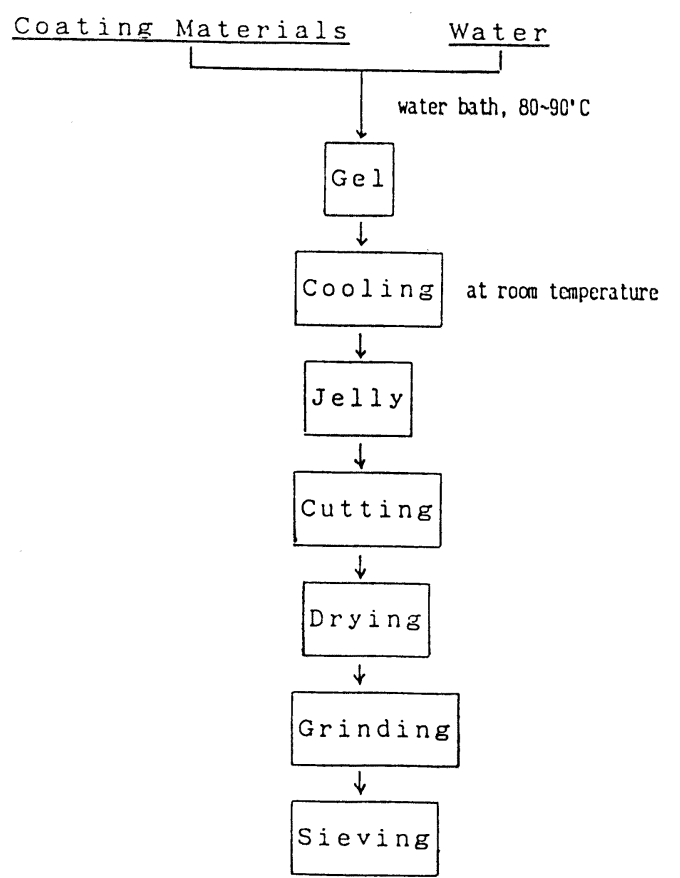

Fig. 1. Procedure in Preparation of Coating Powder

\section{2. コーティング用粉粒体の調製}

調製方法を Fig. 1 に示した.

寒天 $4 \%(\mathrm{w} / \mathrm{v})$, ゼラチン $30 \%(\mathrm{w} / \mathrm{v})$, そして イナアガーL $3 \%(\mathrm{w} / \mathrm{v})$ になるように水を加立, 湯浴で 80〜90 ${ }^{\circ} \mathrm{C}$ に加温してゲル化し, 室温に放 置してゼリーを得る.このゼリーをできるだけ小 さくカットし, 真空乾燥機にて十分に乾燥する. 得られたキセロゲルを錠剤粉砕機あるいはフード プロセッサーを用いて粉砕後42（ゼラチンおよび 寒天）あるいは32メッシュ（イナアガーL）を通 過したものをコーティング用粉粒体として使用し た.

\section{3. コーティング錠の調製}

$\mathrm{KBr}$ 錠剤成形器を用いて, Fig. 2 に模式的に 示した調製方法に従って調製した.

臼中にコーティング用粉粒体を $0.15 \mathrm{~g}$ 充填し, その中心に呉茱莫楊顆粒 $0.3 \mathrm{~g}$ を入れ, その上に コーティング用粉粒体 $0.15 \mathrm{~g}$ をかぶせるように 充填し圧縮圧 $1400 \mathrm{~kg} / \mathrm{cm}^{2}$ で 1 分間加圧し成形し た. 


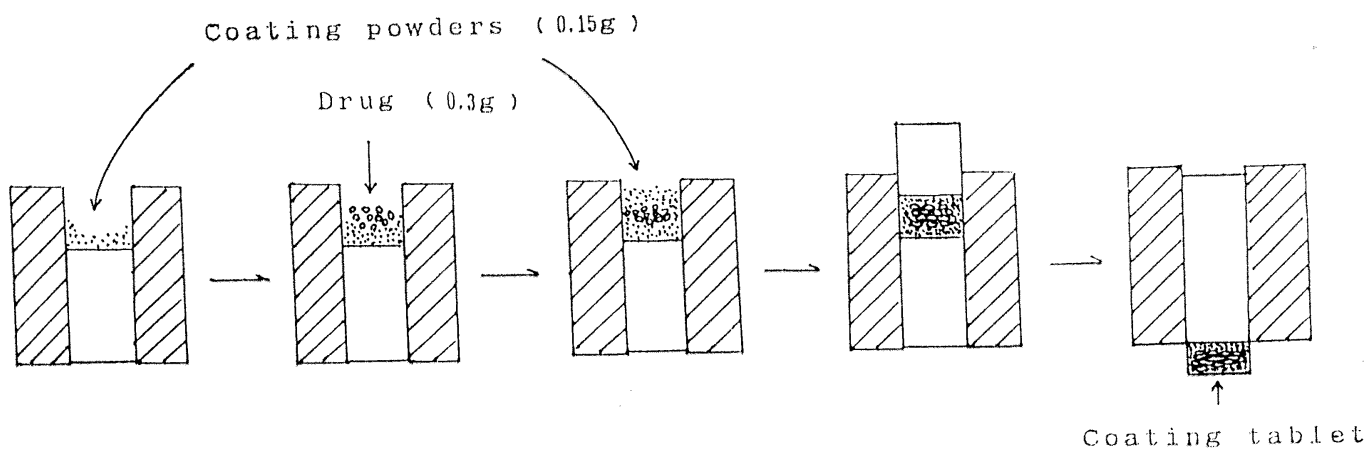

Fig. 2. Procedure in Preparation of Coating Tablet

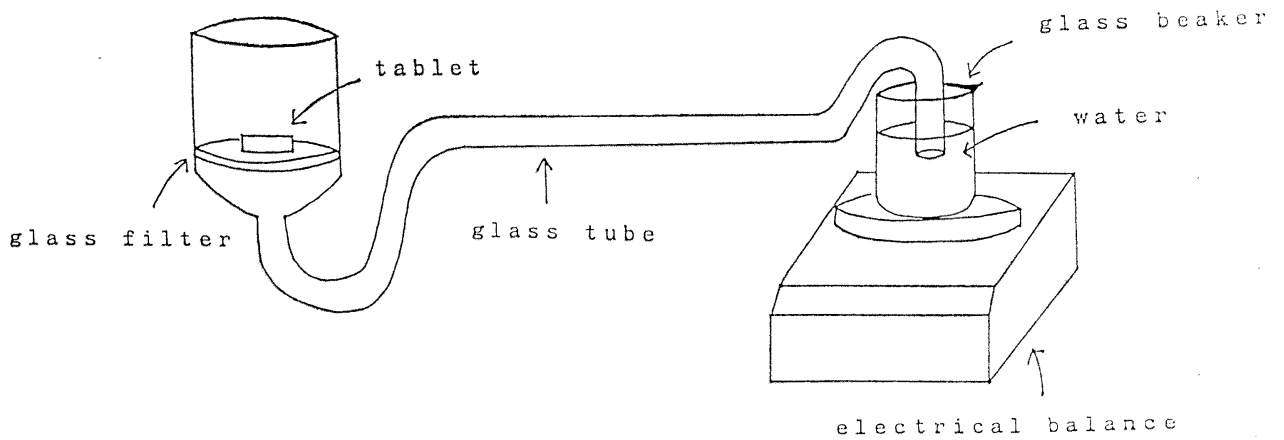

Fig. 3. Water Absorption Apparatus

ゼラチンコーティング錠 $(\mathrm{GL})$, 寒天コーティ ング錠（AG）拈よびイナアガーL コーティング 錠（AL）の 3 種のコーティング錠，また，対照

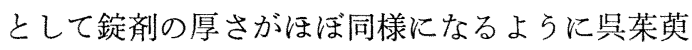
湯顆粒のみ $0.6 \mathrm{~g}$ を同様の条件で加圧成形した受 茉英湯錠 (CT) を調製した.

\section{4. コーティング錠剤の水添加時における膨潤}

\section{状態の観察}

ガラスシャーレ中にコーティング錠剤を置き, 精製水 $0.5 \mathrm{ml}$ を注いだ後, 経時的にコーティン グ層の膨潤状態を写真撮影し比較検討した。な お，操作は室温で行った。 また，膨潤後の錠剤を 分割し割面の写真も撮影し比較検討した。

\section{5 . 吸水試験}

野上ら ${ }^{3)}$ による崩壊剤の吸水膨潤性の評価方法 を参考に Fig. 3 に示すよらな装置を用いて室温
で行った.

コーティング層の吸液によりビーカー中の液量 が減少し電子天科の示す重量が変化する. 経時的 にその值を読み取り吸液量とした。測定は，それ ぞれ 3 回行い平均值を求めた.

\section{6. 崩壊試験}

日局の崩壊試験法4)に準じて行った。試験液は 精製水括よび日局の崩壊試験液第 1 液を用いた。 測定はそれぞれ 3 回行い, 平均值と標準偏差を求 めた。

\section{7. 実用試験}

被験者は60〜71歳の女性 4 名, 男性 1 名の計 5 名の健常人で, 対照の CT および 3 種のコーティ ング錠について行った，大匙に錠剂をのせ，錠剤 が完全に浸る水を入れ，1分間放置後服用し，苦 味の有無および味覚も含めた服用のし易い順位を 
つけてもらった.

\section{8. 吸湿試験}

塩化ナトリウム拉よび硝酸カリウムの飽和溶液 を用いて調湿したデシケーター中（各々相対湿度 $75 \%$ おび92\%) にCT拉よび 3 種のコーティン グ錠を置き $30^{\circ} \mathrm{C}$ に保存した。それぞれ経時的に 重量を測定した。増加した重量を調製直後の重量 で除して重量増加率とした。測定は，各々の3 錠 について行い，その平均值を求めた。

\section{結果および考察}

\section{1. コーティング錠の膨潤状態}

Fig. 4〜6 に各コーティング錠の水添加前の外 観および水添加後の経時的な膨潤状態を示した。

いずれのコーティング錠についても水の添加に より錠剤表面が膨潤し，ゼリ一状を呈しているこ とが観察された。しかし、コーティング用粉粒体 の違いにより経時的な膨潤状態に相違を生じてい ることわかる，AG は $\mathrm{GL}$ および $\mathrm{AL}$ た比べて吸 水膨潤が速く水添加 1 分後からコーティング層が 崩れていく状態が観察された，GL は水添加後
5〜10 分で大きな外観変化が観察された。 そし て AL はコーティング層の崩壊もなく, 水添加後 5 １0分でも大きな外観変化は観察されなかっ た。

Fig. 7 に水添加 10 分後の錠剂の断面写真を示 した。

各コーティング錠とも明らかにコーティング層 のみがゼリー状を呈していることがわかる、コー ティング層が速く崩壊した $\mathrm{AG}$ でも錠剂表面に 膨潤したコーティング層があだ残っていることが 観察された。 また, 経時的外観変化の小さからた $\mathrm{AL}$ でもコーティング層が十分にゼリー状を呈し ていることが観察された。

\section{2. 吸水举動}

Fig. 8 に各コーティング錠の吸水試験の結果 を示す。

$\mathrm{AG}$ は $\mathrm{GL}$ 㘧よび $\mathrm{AL}$ に比べ，はるかに多量で しかも速い吸水挙動を示した. GL および $\mathrm{AL}$ は, それ流ど変わらない少ない吸水量と吸水挙動であ るが5〜10分で GLは急激な吸水量の増加傾向が 認められた。ALは10分まで吸水量の少ない一定

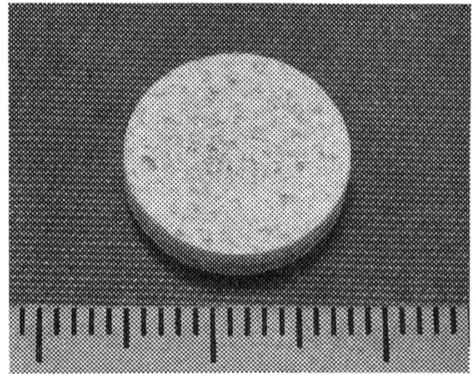

Befor addition of water

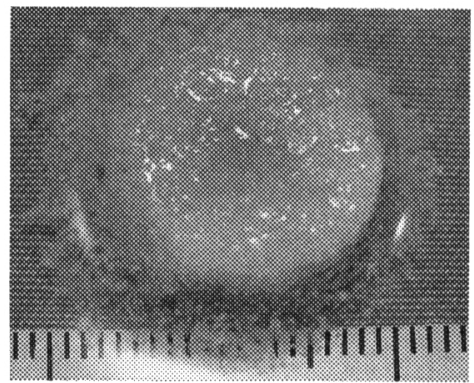

$2 \min$

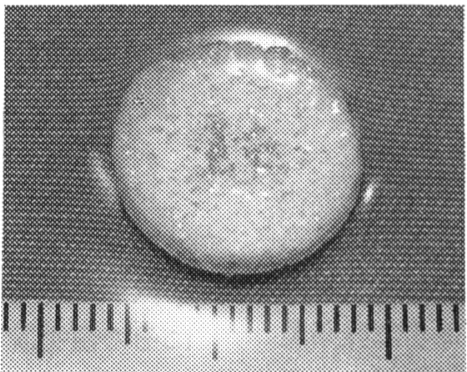

Just after addition of water

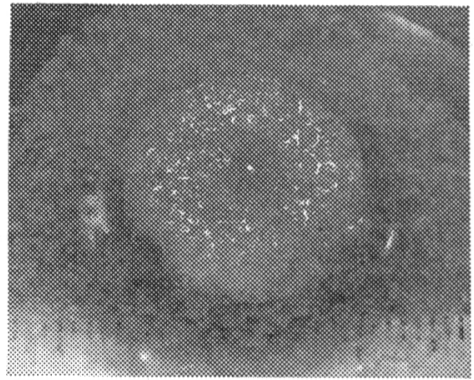

$5 \mathrm{~min}$

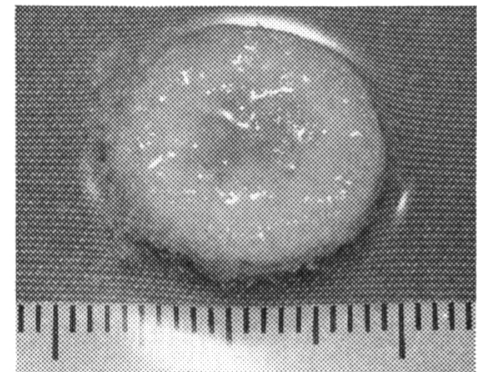

$1 \mathrm{~min}$

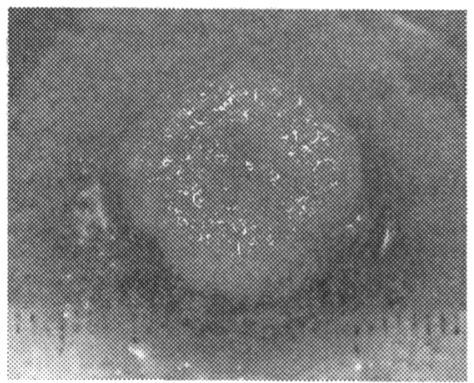

$10 \mathrm{~min}$

Fig. 4. Photographs of Swelling Appearance of Compressed Coating Tablet (AG) 


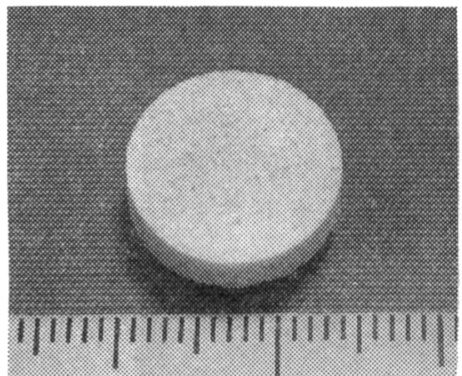

Befor addition of water

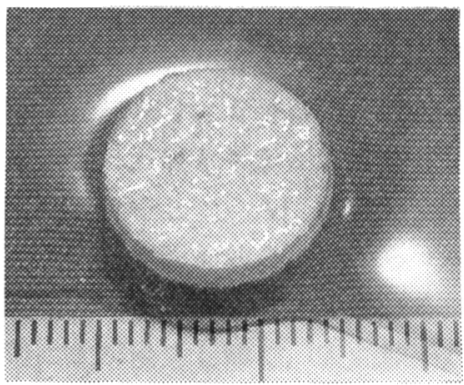

$2 \mathrm{~min}$

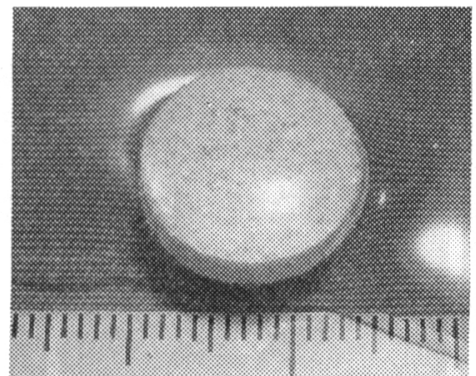

Just after addition of water

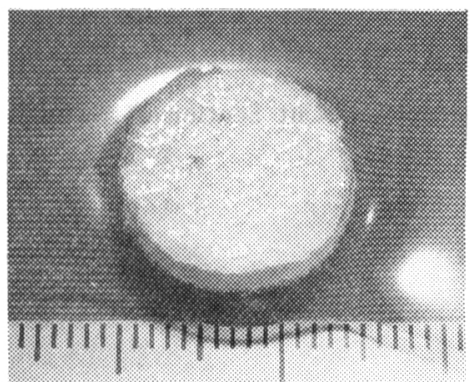

$5 \mathrm{~min}$

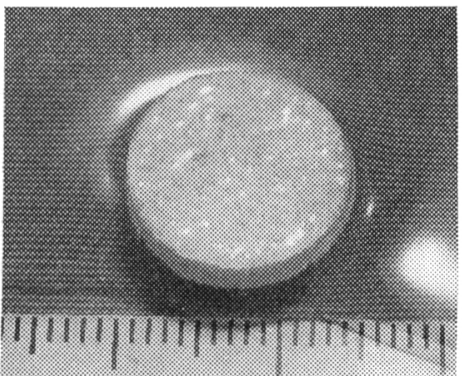

$1 \mathrm{~min}$

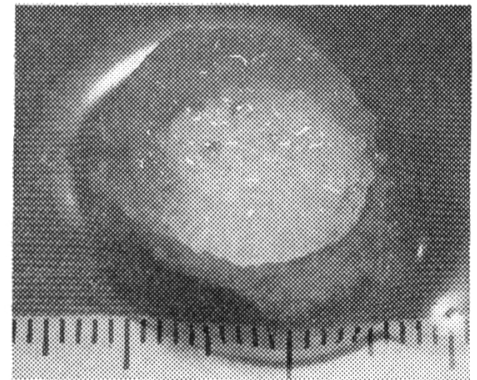

$10 \mathrm{~min}$

Fig. 5. Photographs of Swelling Appearance of Compressed Coating Tablet (GL)

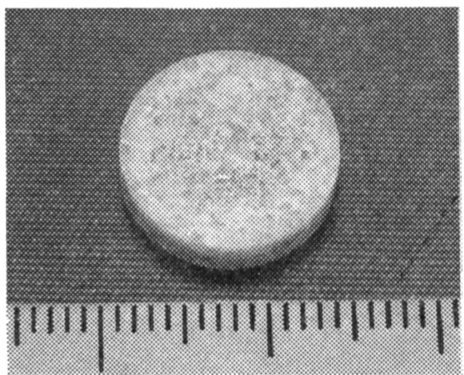

Befor addition of water

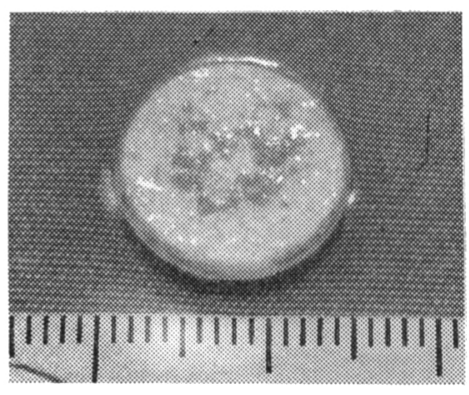

$2 \mathrm{~min}$

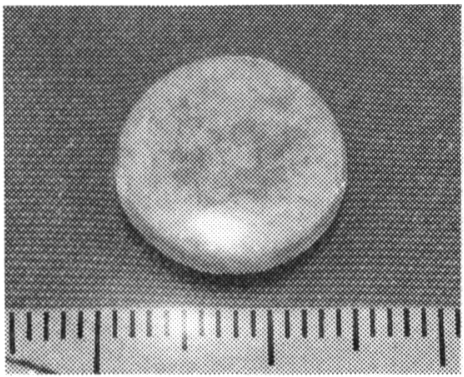

Just after addition of water

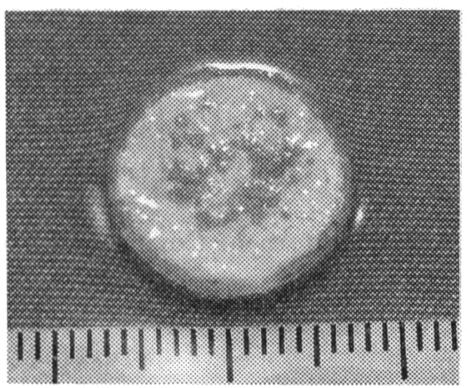

$5 \mathrm{~min}$

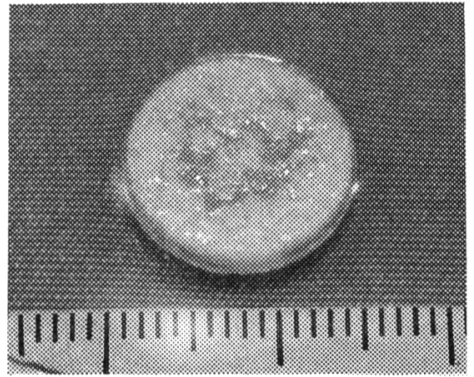

$1 \mathrm{~min}$

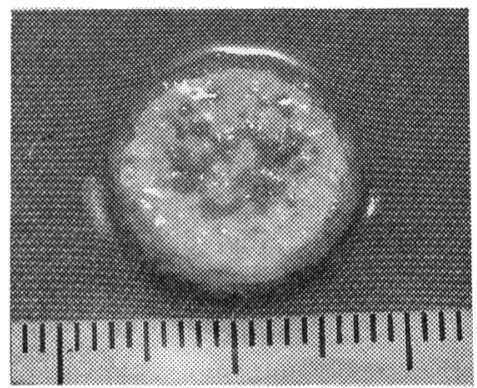

$10 \mathrm{~min}$

Fig. 6. Photographs of Swelling Appearance of Compressed Coating Tablet (AL) 


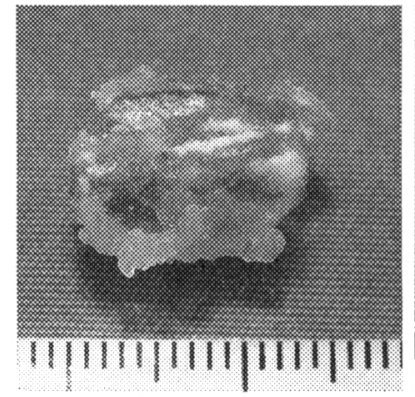

Agar

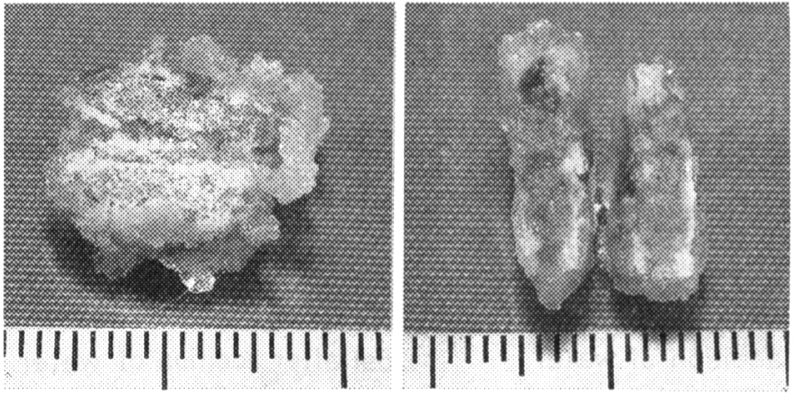

Gelatin

$$
\text { Inaagar- } L^{\ominus}
$$

Fig. 7. Photographs of Cut Section of Swelled Tablet

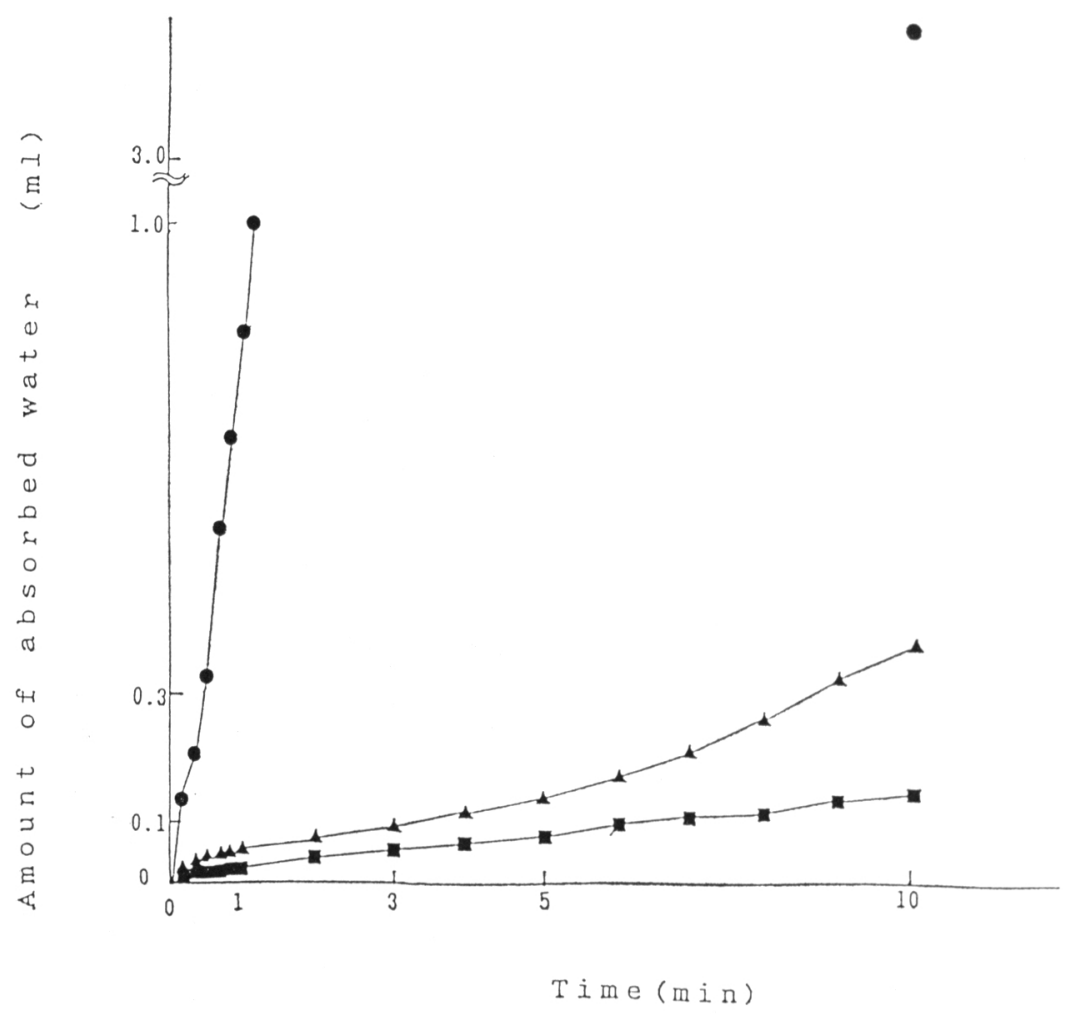

Fig. 8. Water Absorption Pattern of Compressed Coating Tablets Each point represents the mean $(n=3)$

; $\mathrm{AG}, \boldsymbol{\Delta} ; \mathrm{GL}, \mathbf{a}: \mathrm{AL}$ 
の吸水挙動を示した．以上のように各ューティン グ錠の吸水挙動は Fig. 4 6 に示した水添加後の 経時的外観変化をよく裏付けている.

吸水挙動はコーティング用粒子の個々の吸水膨 潤性のみを表するのではなく，コーティング層の 粒子間の空陌の大きさも関係しているものと考兄 られる. AG はコーティング層の速い崩壊から推 測されるよらにコーティング層の粒子間空淂に水 が速やかに浸透し，その後に粒子の膨潤が起こっ ているものと思われる，GL では粒子間空隙に水 が浸透するのが遅く，表面から粒子の吸水膨潤が 徐々に起こり，5分後位から粒子間空隌に水の浸 透が進み，吸水挙動が大きく変化するものと考兄 られる．そして，AL は他のものより粒子が大き いこと，水添加前の外観からコーティング層の形 成が塑性変形によると思われることから粒子間空 隙に水が浸透し難く, 表面粒子から吸水膨潤が進 むものと考兄られる. 以上のことからコーティン グ層の吸水膨潤能の評価はコーティング用粒子の 吸水膨潤能だけでなく，コーティング層の粒子間
空䣣の大きさも含めて行ら必要があることが示唆 された。

\section{3. 崩壊試験}

Fig. 9 亿 $\mathrm{CT}$ および 3 種のコーティング錠の崩 壊試験の結果を示す.

各錠剤とも錠剂表面から崩壊していく過程を 示した．精製水拉よび第 1 液による場 合も AG はCTょりも短い時間で崩壊したが，GL および $\mathrm{AL}$ は，CTょりも崩壊時間が長くなった． AGは 前述したように速やかに吸水してコーティング層 の崩壊が起こるため崩壊時間が短くなるものと思 われる. GL および AL はコーティング層が溶解 して消失するのに時間がかかるため崩壊時間が長 くなるものと考えられる．また，局方においてコ ーティング錠の崩壊は第 1 液を用いて 60 分以内と されている.この結果は各ューティング錠ともこ の基準を満足していることを示している.

\section{4. 実用試験}

水の添加により膨潤した各コーティング錠の苦 味の有無执よび服用のし易さを評価するために行

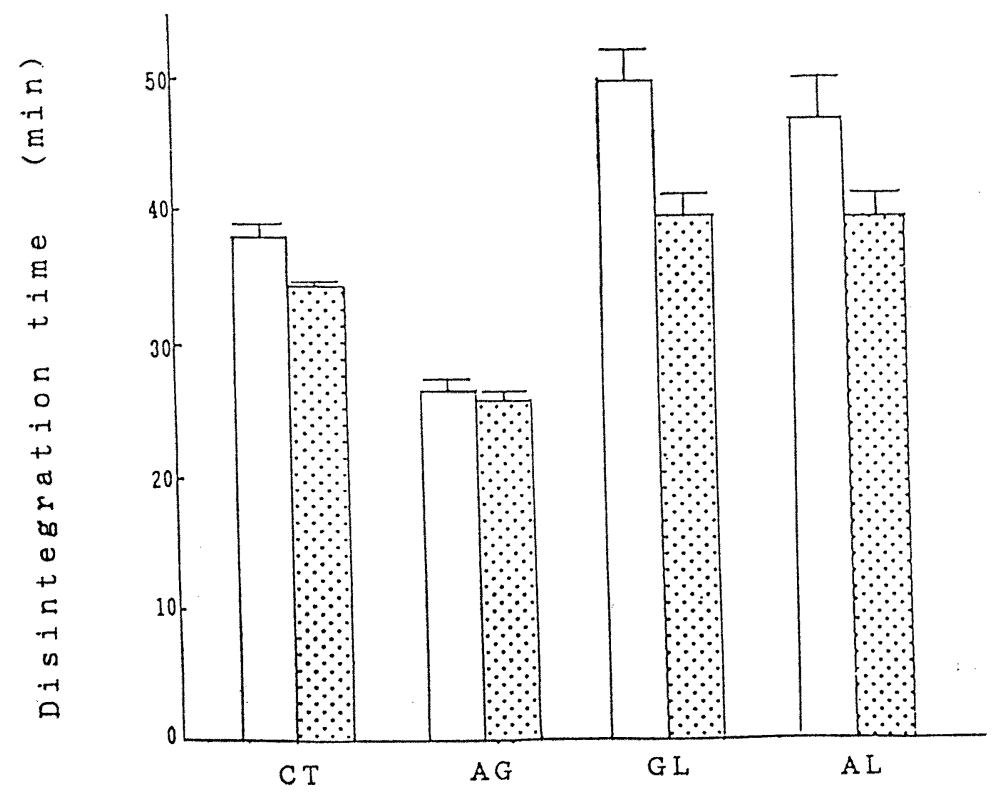

Fig. 9. Disintegration Time of Coating Tablets

Each value is the mean \pm S.D. $(n=3)$

$\square$; Purified water

2 ;P disintegration fluid No.1 ( $\mathrm{pH} 1.2)$ 
Table 2. Results of Test in Volunteers for Coating Tablets

\begin{tabular}{|c|c|c|c|c|c|c|c|c|c|c|}
\hline \multirow[b]{2}{*}{ Volunteer } & \multirow[b]{2}{*}{ Sex } & \multirow[b]{2}{*}{$\mathrm{Ag} \mathrm{e}$} & \multicolumn{4}{|c|}{ Bitter taste } & \multicolumn{2}{|c|}{ Favorite } & \multicolumn{2}{|c|}{ ranking } \\
\hline & & & $\mathrm{CT}$ & $\Lambda G$ & G I & $A L$ & $\mathrm{CT}$ & $\Lambda \mathrm{G}$ & G L & $\mathrm{Al}$ \\
\hline A & $\mathrm{F}$ & 67 & + & - & - & - & 4 & 1 & 2 & 3 \\
\hline B & $\mathrm{F}$ & 62 & + & - & - & - & 4 & 3 & 2 & 1 \\
\hline $\mathrm{C}$ & $\mathrm{F}$ & 69 & + & - & - & - & 2 & 3 & 4 & 1 \\
\hline D & $\mathrm{F}$ & 60 & + & - & - & - & 4 & 3 & 2 & 1 \\
\hline $\mathrm{E}$ & $M$ & 71 & + & - & - & - & 3 & 4 & 2 & 1 \\
\hline
\end{tabular}

CT; Gosyuyutou tablet

$\Lambda G ; A g a r c o a t j n g$ Lablet

GL ; Gelatincoating tablet $\Lambda I$; Inagar-I, e caling tablet

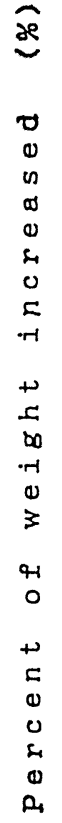

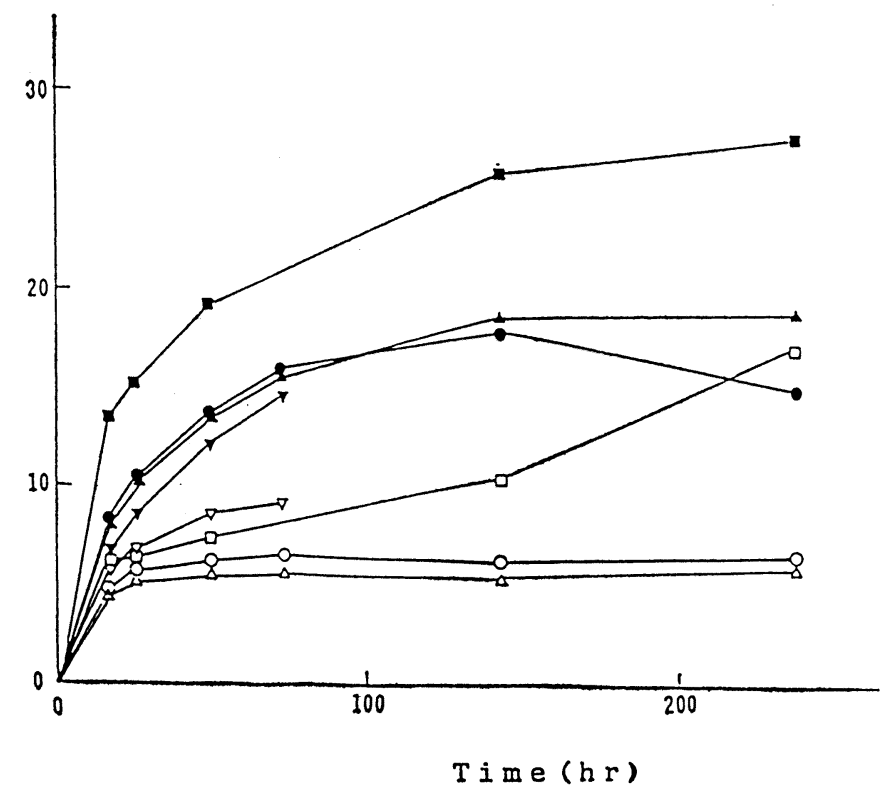

Fig. 10. Moisture Absorption Pattern of Tablets Each point represents the mean $(n=3)$

$\nabla$; CT (R.H.92\%), O AG (R.H.92\%), A ; GL (R.H.92\%),

口; AL (R.H.92\%) $\nabla$; CT (R.H.75\%), O : AG (R.H.75\%), $\triangle$; GL (R.H.75\%), $\square$; AL (R.H.75\%) 
つた試験の結果をTable 2 に示す.

苦味の有無については対照とした CT は全員苦 味を感じるが，各ューティング錠は苦味を感じな いといら結果を得た。このことから，本錠は吸水 膨潤後でも味のマスキングがなされていることが わかった．また，いずれのコーティング錠も喉へ 付着するという指摘もなく, 服用のし易さの順位 では AL が最も好まれ, 次いで GL, AGの順で あり, 各コーティング錠ともCTよりは好ましい と感じていることがわかる. AG はコーティング 層の崩壊が認められたことから服用時にコーティ ング粒子がロ中に残るため好まれなかったと思わ れる. AL と GL は水添加 1 分後ではほぼ同様の 吸水挙動であることから膨潤状態に大きく差があ るとは考え難いＡＡは食品用のゼリーの素であ ク, Table 1 に示したように多量の添加物が含ま れ，食感の面で工夫されていると推測される．そ のため吸水膨潤してゼリー状になった時の食感が 良いため最も好まれたものと考えられる．以上の ことから服用のし易さには吸水膨潤後の食感も考 慮する必要があることが示唆された。

\section{5. 吸湿举功}

温度 $30{ }^{\circ} \mathrm{C}$ ， 相対湿度 $75 \%$ および $92 \%$ 下での CTおよび各コーティング錠の保存時の経時的な 吸湿挙動を Fig. 10 に示す. CT はいずれの保存 条件下でも 3 日目までで, かびの発生が観察され たためそこまでの挙動を示した。

相対湿度 $75 \%$ の条件下では各コーティング錠は 1 日で5〜6\%の重量増加を示した. その後 $\mathrm{AG}$ および GLはほほ平衡状態となり，CT の吸湿を 抑える傾向がみられた。しかし，AL は重量増加 率が大きくなり，10日後には約16\%の重量增加を 示した。 また，相対湿度 $92 \%$ の条件下ではいずれ もCTよりも吸湿し，AG および GLは1 日で約 $8 \%$ 重量増加を示し, その後も徐々に重量増加 が認められ平衡時には約 $18 \%$ の重量增加を示し たＡL は 1 日で約 $13 \%$ もの重量増加を示し, 10 日後です重量の增加傾向が認められた。このよう に，最も好まれた AL は他に比べて吸湿性の高 いことがわかった．以上のことから本錠は包装な
どで防湿する必要があると思われた。

\section{結論}

従来の剂形では服用できない高龄者にも服用し 易い剂形の開発を目的として寒天，ゼラチンおよ び食品用ゼリーの素イナアガーLを用いて調製し た各キセロゲルをコーティング層とする吸水膨潤 型圧縮コーティング錠の基礎的検討を行い，以下 のような結果を得た.

1）各錠とも味のマスキングが可能で水の添加 により錠剤表面がゼリー状となることが確認され た. また，局方におけるコーティング錠の崩壊試 験の基準を満足した．しかし，保存条件によって は吸湿性が高く，包装などで防湿する必要がある と思われた。

2）吸水膨潤挙動はコーティング用試料の相違 により異なり，寒天では吸水速度は速いがューテ ィング層の崩壊が観察された。吸水膨潤挙動の違 いはコーティング層の粒子間空隙および粒子の膨 潤性の相違によるものと推測された。また，実用 試験の結果, イナアガーLが最も好まれたことか ら膨潤後の食感も重要な要因であること考えられ た. 以上のことからコーティング層の性質として 速やかな膨潤と膨潤後のコーティング層の保持お よび適当な食感を有することが望まれ，これらの 面でさらに検討が必要であると思われた。

3）本錠は最適なコーティング層の調製ができ れば，薬物の制約もなく，味のマスキングも可能 で従来の剂形では服用できない高龄者に対して有 用な剂形となることが示唆された。

\section{引用文 献}

1）杉原正泰, 粟津荘司, 上田慶二, 武田 圌, 福室 憲治, 厚生省厚生科学研究補助金シルバーサイエ ンス研究, 昭和62年度研究報告, (追補), 1988.

2）伊那食品工業株式会社資料

3) H. Nogami, T.Nagai, E. Fukuoka, T. Sonobe, Chem.Pharm. Bull., 17, 1450-1455 (1969).

4) 日本公定書協会編, “第十二改正日本薬局方解説 書”一般試験法 (崩壊試験法), 広川書店, 東京, 1991. 